DOI: $10.12775 / \mathrm{MBS} .2014 .001$

Medical and Biological Sciences, 2014, 28/1, 5-10

ORIGINAL ARTICLE / PRACA ORYGINALNA

Jerzy Eksterowicz, Marek Napierała

\title{
SIZE OF SELECTED SOMATIC PARAMETERS OF PHYSICAL EDUCATION STUDENTS AT KAZIMIERZ WIELKI UNIVERSITY IN BYDGOSZCZ IN THE YEARS 2006 - 2012
}

\author{
WIELKOŚCI WYBRANYCH PARAMETRÓW SOMATYCZNYCH STUDENTÓW \\ UNIWERSYTETU KAZIMIERZA WIELKIEGO W BYDGOSZCZY \\ Z KIERUNKU WYCHOWANIE FIZYCZNE NA PRZESTRZENI LAT 2006 - 2012
}

\author{
Institute of Physical Education, Kazimierz Wielki University in Bydgoszcz \\ Head: dr hab. Radosław Muszkieta, prof. UKW
}

Sum mary

The work is to determine the size of the selected somatic indicators and some morphological features of fulltime students of physical education at Kazimierz Wielki University of Bydgoszcz in the years 2006-2012. All results are presented in tables and some of them as graphics.

To characterize the type of somatic structure, the following indicators were calculated for men and women: BMI, WHR, AMC and Rohrer index. Also body fat (BF) and fat-free mass (FFM) were determined.
It is worth noting that the surveyed students, both men and women, in addition to physical activity resulting from their studies (physical education), in many cases practise sport at the competitive or recreational level. This implies the desired body structure characterized by low fat, large musculature and sufficient height and could make a somatic homogeneity of the studied group.

Streszczenie

Praca ma na celu określenie wielkości wybranych wskaźników somatycznych i niektórych cech morfologicznych studentów studiów stacjonarnych z kierunku wychowania fizycznego Uniwersytetu Kazimierza Wielkiego Bydgoszczy w latach 2006-2012. Wszystkie wyniki zostały przedstawione tabelarycznie a część graficznie.

Dla scharakteryzowania typu budowy somatycznej obliczone zostały dla mężczyzn i kobiet następujące wskaźniki: BMI, WHR, AMC i wskaźnik Rohrera. Określono również zawartość tkanki tłuszczowej (BF) i beztłuszczowej masy ciała (FFM).

Key words: working time structure, paediatric unit, nursing care

Stowa kluczowe: struktura czasu pracy, oddział pediatryczny, opieka pielęgniarska

\section{INTRODUCTION:}

Human somatic structure can be a source of satisfaction or, conversely, a source of complexes and disapproval of one's own body. It depends on many
Warto podkreślić, że badani studenci zarówno kobiety jak i mężczyźni, oprócz aktywności fizycznej wynikającej z kierunku studiów (wychowanie fizyczne), $\mathrm{w}$ wielu przypadkach intensywnie uprawiają sport na poziomie wyczynowym i rekreacyjnym. Implikuje to pożądaną budowę ciała charakteryzującą się niskim otłuszczeniem, znacznym umięśnieniem oraz odpowiednio dużym wzrostem i może stanowić o jednorodności somatycznej badanej grupy. factors, which can be generally divided into three groups: genetic, environmental and behavioural. Genetic factors are transmitted to a man at the moment of conception through the chromosomes located in the cell nucleus where the genes are stored with 'instructions' on the properties of the body 
development. It should be noted that the structural development of a man is not a uniform process and it is influenced by internal mechanisms and environmental impacts, in terms of both quantity and quality. This can be relatively easily noted when focusing on the speed of maturation, development and aging of human body organs [1]. Even a cursory observation shows that in children experiencing pubertal spurt, the body length growth does not take place in a proportionate manner. Hence, the morphological proportions of young people's build are sometimes temporarily disrupted. The growth mechanism of single parts of the body length is genetically controlled, and yet is not exactly recognized. However, it should be noted that the development of a living organism is the result of interaction of genes and environment. Genes determine the standard of body responsiveness to environmental factors and can manifest themselves differently in various environmental conditions, for example in the amount of fat tissue [2].

Finally, the third factor determining the development of an individual that creates conditions for the survival of the species and affects the somatic state is behaviourism the behaviour of an individual in particular environmental conditions. In some cases specific behaviour of an individual helps to fight the adversities encountered during the ontogenesis and to promote the development (physical and mental). However, it may lead to the loss of elements that sustain health and life of entire populations.

The purpose of this study was to determine the size of selected parameters of the human body among full-time students (men and women studying physical education) at the Bydgoszcz University in the years 2006-2012, for each year separately. The second objective was to compare the tabular data and the size of somatic features of students over seven years of the study. They document the somatic changes in the researched population.

\section{MATERIAL AND METHODS:}

The study was conducted among full-time students aged 19-26 (men and women studying physical education) of Bydgoszcz University in the period from 2006 to 2012 . The study was carried out in July, once every year, during a summer training camp. The following anthropometric measurements were examined (in $\mathrm{cm})$ : body height $(\mathrm{V}-\mathrm{B})$, arm length (a - r), forearm length ( $\mathrm{r}$ - sty), upper limb length (a - da III), leg length (tro - B), foot length (ap - pte), shoulders width (a - a), hips width (c - c), pelvis width (is - is), arm width (mm $\mathrm{mu})$, palm width $(\mathrm{mr}-\mathrm{mu})$ foot width $(\mathrm{mtt}-\mathrm{mtf})$. In addition, also the chest at full inspiration and expiration was measured (in $\mathrm{cm}$ ) as well as the following circumferences: waist, hips, flexed and unflexed arm, thigh and calf. The body weight was measured as well (in $\mathrm{kg}$ ). The elements that were measured also include (in mm): thickness of three skinfolds located over the triceps (TSF) (triceps skinfold), vertical skinfold, the lower angle of the shoulder blades (SCSF) (subscapular skinfold), horizontal skinfold, and above the iliac crest (SISF) (suprailiac skinfold), diagonal skinfold. Based on these measurements the following parameters were calculated: Body Mass Index (BMI, kg/m2), Arm Muscle Circumference (AMC), Waist to Hip Ratio (WHR), Fat Mass (FM) (kg), percentage of body fat $(\mathrm{FM}, \%)$ and lean body mass in kilograms and percentage (FFM, kg) (FFM, \%) [3].

The measurements were taken using a portable TANITA BF 662M medical scale and anthropometric toolkit (anthropometer, tape meter, skinfold calliper) made by a Swiss company Siber Hegner \& Co. Ltd.

From the measurements the average values and standard deviations were calculated and the statistical inference was carried out comparing the examined parameters to each other. The statistical differences were determined between the mean values calculated for the years 2006-2012 and the examined parameters in the consecutive years of the study. The material was presented in a tabular form and the part of the results selected by the authors is also illustrated graphically taking into account the statistical variation. The average values were assumed and the significance of differences are shown at the levels of $5 \%$ and $1 \%$ of confidence.

\section{THE RESULTS ANALYSIS:}

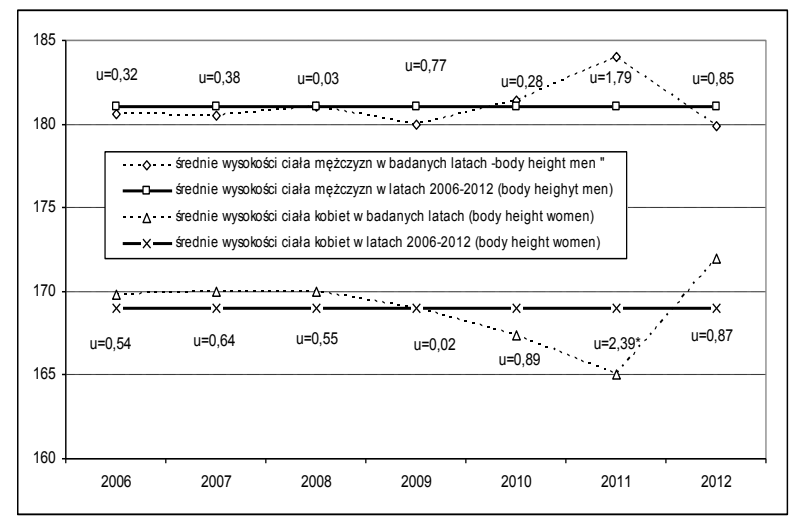

Fig. 1. The body height of men and women (in $\mathrm{cm}$ ) in the years 2006 - 2012 compared to the average value from the examined years

$* p<0.05 ; \quad * * p<0.01 ; \quad t \alpha=0,05 ; \quad d f=\infty=2.00 ; \quad t \alpha=$ 0,$01 ; d f=\infty=2.66$ (applies to all graphics)

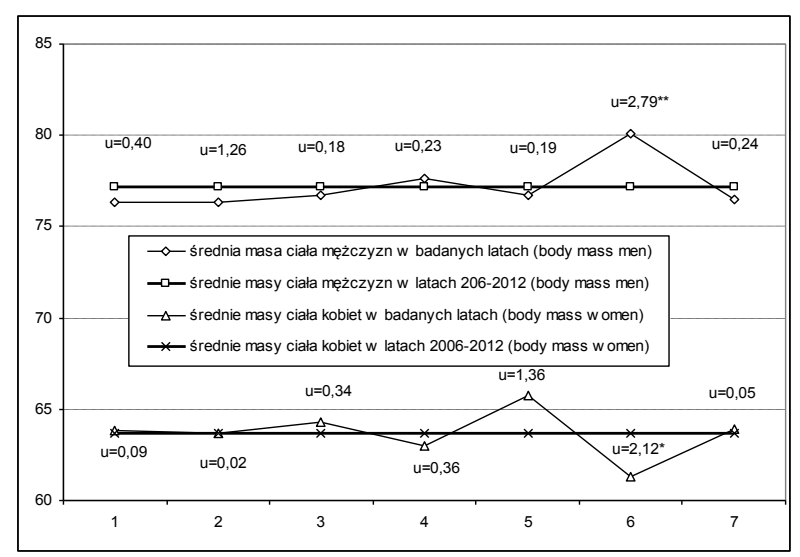

Fig. 2. The body weight of men and women (in $\mathrm{cm}$ ) in the years 2006 - 2012 compared to the average value from the examined years

The biggest differences between the height and weight of the respondents compared with the average from examined years occurred in 2011 (Fig. 1, 2). Men accepted to the physical education studies turned out to be the highest and had the largest weight (statistical difference at $1 \%$ ), while the group of women was characterized by the lowest height and weight (statistical difference at $5 \%$ ). 


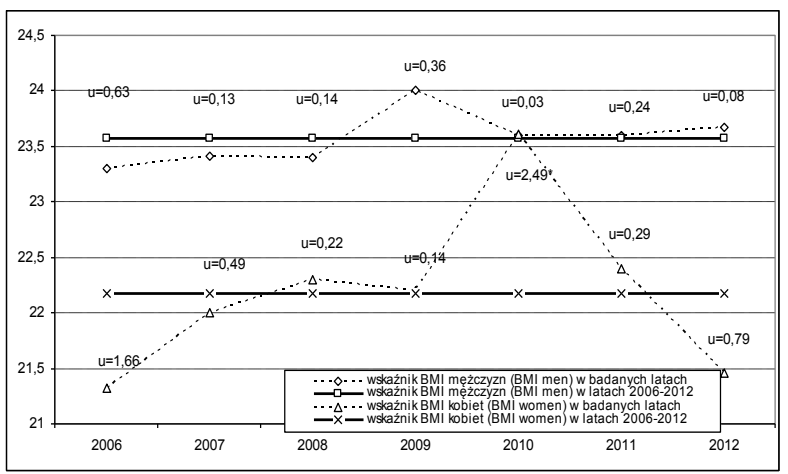

Fig. 3. The BMI of men and women in the years $2006-2012$ compared to the average value from the examined years

BMI of men did not change during the examined years, the results were very similar. In case of women only in the year 2010 a variation of 5\% was noted (women had higher parameters) (Fig. 3).

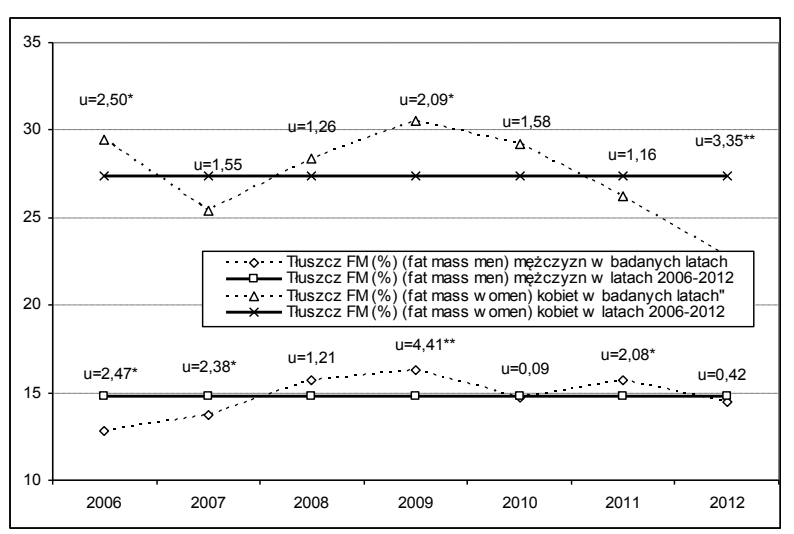

Fig. 4. The percentage of fat mass (FM, \%) in the years 2006 2012 compared to the average value from the examined years

The percentage of fat mass (FM, \%) in the period of 2006-2012 compared to the average value from the examined years was evolving. It was lower than average in the group of men in the years: 2006, 2007 (at the level of 5\% of confidence), and higher in the years: $2009(1 \%)$ and 2011 (5\%).

The women subjected to the research in 2006 and 2009 had a higher percentage of fat (level of confidence at $5 \%$ ), while in 2012 their amount of fat was reduced to the level of 1\% (Fig. $4)$.

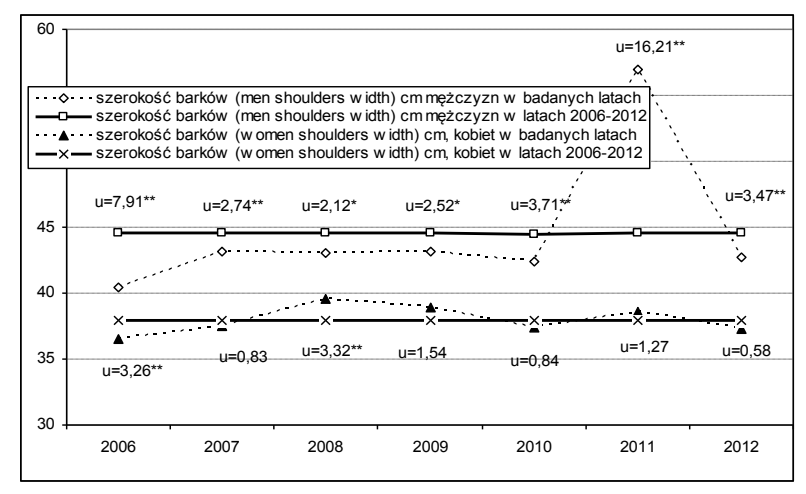

Fig. 5. The shoulders width of men and women in the years 2006 - 2012 compared to the average value from the examined years.
The width of the shoulders of men over the compared years was smaller than the average in the years: 2006, 2007, 2010, 2012 (a difference of 1\%) and in 2008, 2009 (5\%). The greatest width of the shoulders occurred in the year of 2011 (a difference of 1\%). Among the researched women, broader shoulders than the average were noted in 2006 and in 2008 (at the level of 1\%) (Fig. 5).

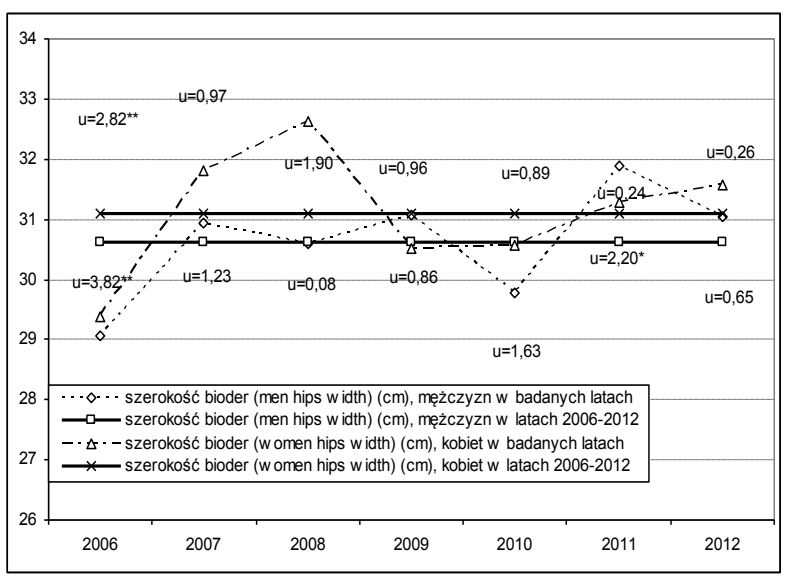

Fig. 6. The hip width of men and women in the years 2006 2012 compared to the average value from the examined years

When comparing the mean values of the hips width of men, it can be stated that the differences were statistically significant only in 2006 (1\%) and 2011 (5\%), while among women in 2006 (1\%) (Fig. 6).

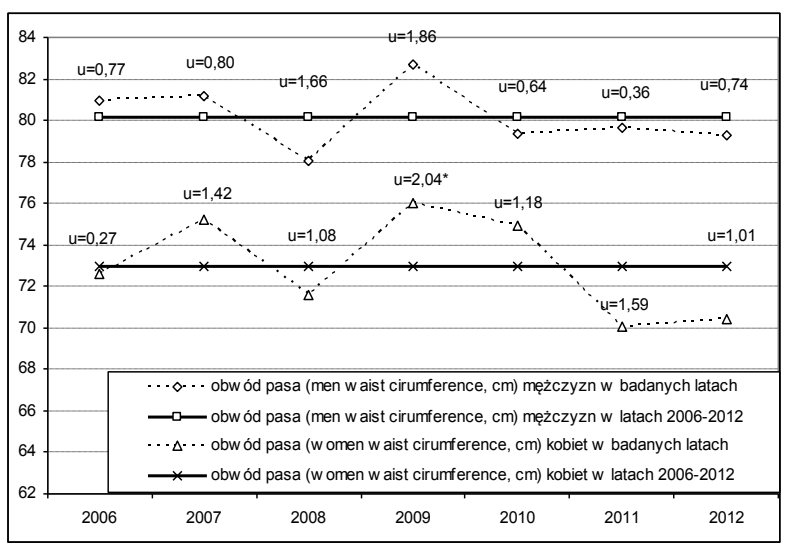

Fig. 7. The waste circumference of men and women in the years 2006 - 2012 compared to the average value from the examined years

When measuring the waist circumference of men, it should be noted that the differences between the mean values in each year and the average for the entire period of the study were not statistically significant. Only in the group of women, in 2009, a larger circumference than the average value was observed (the statistically significant difference of 5\%) (Fig. 7). 


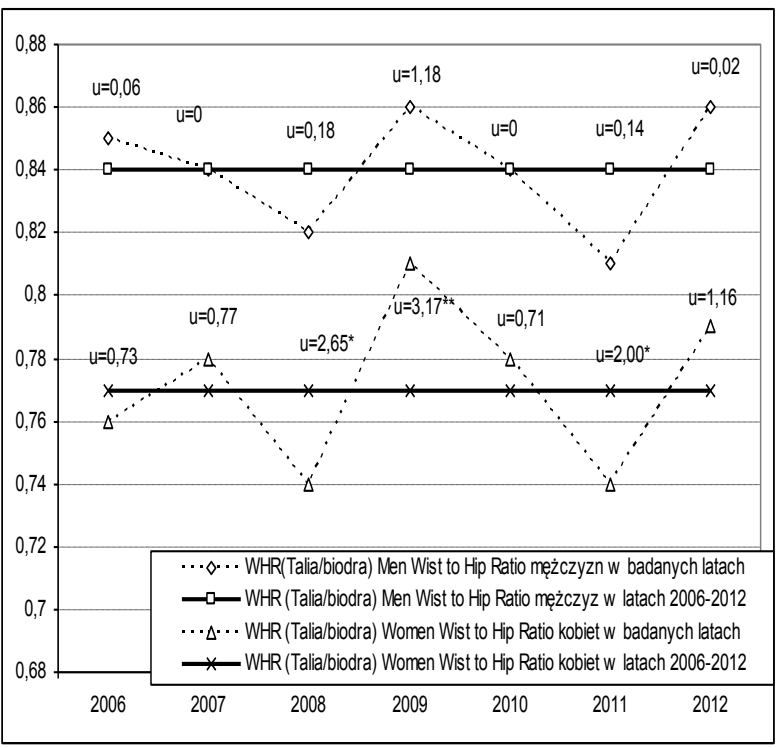

Fig. 8. The WHR of men and women in the years $2006-2012$ compared to the average value from the examined years

When comparing the mean values of WHR of men in the consecutive years with the average value for the years 2006 - 2012, no statistically significant differences were observed. In the group of women the parameter was smaller and statistically significant in 2008, 2011 (5\%), and higher in 2009 (1\%) (Fig. 8).

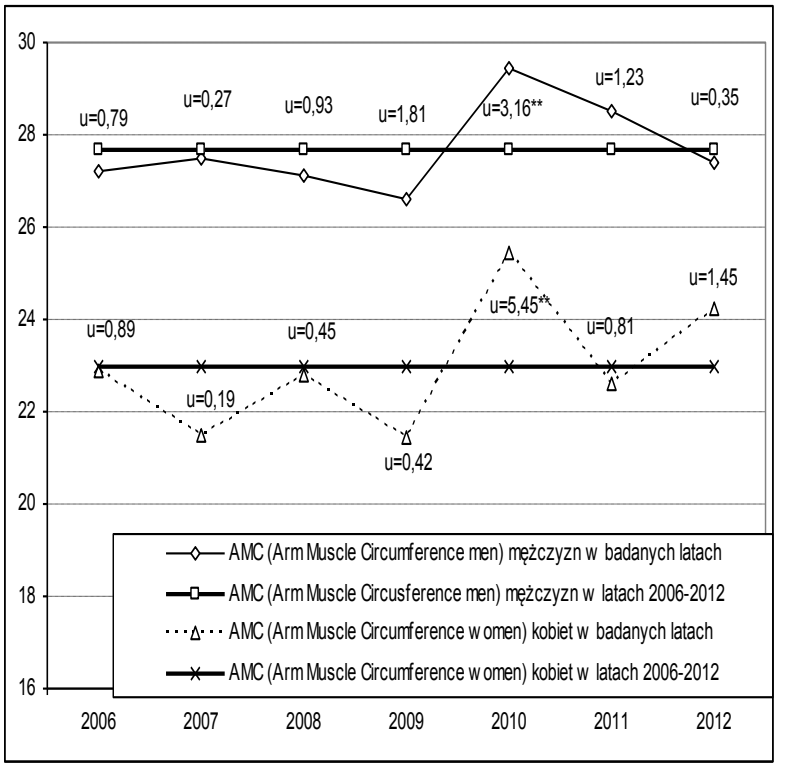

Fig. 9. The AMC of men and women in the years $2006-2012$ compared to the average value from the examined years

The AMC indicator in the researched groups of men and women underwent minor changes over the years (the difference was not statistically significant). In 2010, it was higher than average in both groups and the differences were statistically significant at the level of $1 \%$ (Fig. 9).

\begin{tabular}{|c|c|c|c|c|}
\hline \multirow[t]{2}{*}{ Tested feature } & \multicolumn{2}{|c|}{$\begin{array}{c}\text { 2006-2012 } \\
\text { Mężczyźni } \\
\text { Men } \\
\mathrm{N}=33\end{array}$} & \multicolumn{2}{|c|}{$\begin{array}{c}\text { 2006-2012 } \\
\text { Kobiety } \\
\text { Women } \\
\mathrm{N}=31\end{array}$} \\
\hline & $\overline{\bar{X}}$ & S & $\overline{\bar{X}}$ & S \\
\hline Wysokość (body height) $(\mathrm{cm})$ & 181,05 & 6,50 & 169,03 & 7,03 \\
\hline Masa ciała( body mass) (kg) & 77,11 & 8,85 & 63,67 & 8,27 \\
\hline Wskaźnik BMI ( body mass index) & 23,57 & 2,07 & 22,18 & 2,06 \\
\hline Proc. zawartość tł.FM (\%) (fat mass) & 14,77 & 3,02 & 27,42 & 3,47 \\
\hline Szer. barków (a-a) (shoulders width) (cm) & 44,56 & 2,24 & 37,98 & 2,26 \\
\hline Szerokość bioder (ic-ic) (hips width) (cm) & 30,63 & 2,05 & 31,1 & 3,01 \\
\hline Ob. pasa (waist cirumference) $(\mathrm{cm})$ & 80,16 & 5,07 & 72,96 & 6,30 \\
\hline WHR (Talia / biodra) Wist to Hip Ratio & 0,84 & 0,77 & 0,77 & 0,05 \\
\hline AMC Arm Muscle Circumference & 27,69 & 2,61 & 22,99 & 0,37 \\
\hline
\end{tabular}

$\mathrm{N}$ - numbers , $\bar{X}-$ average value, $\mathrm{S}$ - standard variation

Table 1. The somatic characteristics of average values and standard deviation in men and women in the years 2006 - 2012 


\begin{tabular}{|c|c|c|c|c|c|c|c|c|c|c|c|c|c|c|}
\hline \multirow[b]{2}{*}{ Tested feature } & \multicolumn{2}{|c|}{$2006 \mathrm{~N}=41$} & \multicolumn{2}{|c|}{$2007 \mathrm{~N}=37$} & \multicolumn{2}{|c|}{$2008 \mathrm{~N}=32$} & \multicolumn{2}{|c|}{$2009 \mathrm{~N}=43$} & \multicolumn{2}{|c|}{$2010 \mathrm{~N}=26$} & \multicolumn{2}{|c|}{$2011 \mathrm{~N}=20$} & \multicolumn{2}{|c|}{$2012 \mathrm{~N}=29$} \\
\hline & $\overline{\bar{X}}$ & $\mathrm{~S}$ & $\overline{\bar{X}}$ & S & $\overline{\bar{X}}$ & $\mathrm{~S}$ & $\overline{\bar{X}}$ & S & $\overline{\bar{X}}$ & $\mathrm{~S}$ & $\overline{\bar{X}}$ & S & $\overline{\bar{X}}$ & $\mathrm{~S}$ \\
\hline Wysokość (body height) $(\mathrm{cm})$ & 180,58 & 6,07 & 180,5 & 7,79 & 181,0 & 8,01 & 180,0 & 5,0 & 181,4 & 6,01 & 184,0 & 5,53 & 179,87 & 7,11 \\
\hline Masa ciała( body mass) $(\mathrm{kg})$ & 76,31 & 8,10 & 76,3 & 8,43 & 76,7 & 9,70 & 77,6 & 9,6 & 76.7 & 7,91 & 80,1 & 10,1 & 76,48 & 8,13 \\
\hline Wskaźnik BMI ( body mass index) & 23,3 & 1,51 & 23,41 & 2,11 & 23,40 & 1,70 & 24,0 & 2,40 & 23,6 & 1,91 & 23,6 & 2,4 & 23,67 & 2,49 \\
\hline Masa thuszczu w ciele FM (kg) (fat mass) & 9,21 & 2,58 & 10,6 & 2,87 & 12,23 & 3,62 & 12,86 & 4,09 & 11,41 & 2,89 & 12,78 & 3,58 & 11,18 & 3,10 \\
\hline Procentowa zawartość thuszczu FM (\%) (fat mass) & 12,79 & 3,79 & 13,7 & 2,72 & 15,73 & 3,14 & 16,26 & 3,13 & 14,74 & 2,60 & 15,72 & 2,82 & 14,45 & 2,95 \\
\hline Beztluszczowa masa ciała FFM (fat free mass) (kg) & 67,10 & 6,66 & 65,7 & 6,70 & 64,48 & 7,17 & 64,73 & 6,05 & 65,27 & 5,85 & 67,33 & 7,40 & 65,30 & 5,96 \\
\hline Bezthuszczowa masa ciała FFM (fat free mass) (\%) & 87,20 & 3,79 & 86,3 & 3,48 & 84,27 & 3,14 & 83,74 & 3,13 & 85,26 & 2,60 & 84,28 & 2,82 & 85,55 & 2,95 \\
\hline Fałd pod topatką (subscapular skinfold) $(\mathrm{mm})$ & 9,91 & 2,51 & 10,38 & 2,08 & 10,81 & 2,61 & 10,50 & 2,60 & 10,41 & 1,91 & 10,5 & 2,2 & 10,28 & 2,80 \\
\hline Fałd nad tricepsem (skinfold over triceps) $(\mathrm{mm})$ & 6,51 & 2,92 & 8,08 & 2,77 & 9,0 & 2,01 & 10,3 & 2,7 & 8,62 & 2,32 & 9,1 & 1,9 & 8,28 & 1,69 \\
\hline Fałd nad biodrem (suprailiac skinfold) $(\mathrm{mm})$ & 8,41 & 3,02 & 9,37 & 4,08 & 10,5 & 3,3 & 10,7 & 2,9 & 9,11 & 2,32 & 10,8 & 3,2 & 9,02 & 2,78 \\
\hline Suma fałdów (skinfolds in total) $(\mathrm{mm})$ & 27,5 & 6,10 & 27,83 & 5,34 & 30,3 & 6,70 & 31,5 & 7,6 & 28,01 & 5,34 & 30,4 & 6,5 & 27,57 & 6,18 \\
\hline D1. ramienia $(\mathrm{a}-\mathrm{r})(\mathrm{arm}$ length $)(\mathrm{cm})$ & 30,48 & 2,87 & 30,10 & 3,13 & 32,51 & 2,51 & 32,40 & 2,78 & 32,52 & 1,63 & 33,37 & 2,38 & 30,90 & 2,17 \\
\hline Dł. przedramienia $(\mathrm{r}-$ sty) (forearm length) $(\mathrm{cm})$ & 25,85 & 1,62 & 26,75 & 2,05 & 27,43 & 1,86 & 25,86 & 2,49 & 27,84 & 2,33 & 25,94 & 2,11 & 25,89 & 1,90 \\
\hline Dł. kończyny górnej (a-daIII) (upper limb length) (cm) & 79,25 & 3,04 & 81,20 & 5,76 & 79,45 & 3,95 & 79,17 & 4,72 & 80,18 & 3,86 & 80,76 & 4,22 & 78,07 & 3,98 \\
\hline Dł. kończyny dolnej (tro-B) (leg length) $(\mathrm{cm})$ & 90,86 & 3,88 & 96,00 & 5,68 & 91,88 & 3,89 & 91,08 & 4,72 & 90,77 & 4,69 & 93,42 & 6,13 & 91,21 & 4,88 \\
\hline D1. stopy (pte-ap) (foot length) (cm) & 26,85 & 2,78 & 27,02 & 3,05 & 27,15 & 1,51 & 26,46 & 1,18 & 26,81 & 1,34 & 27,80 & 1,62 & 26,57 & 1,08 \\
\hline Długość tułowia (a-tro) (torso length) $(\mathrm{cm})$ & & & & & & & & & 57,10 & 2,97 & 56,17 & 2,74 & 55,73 & 4,79 \\
\hline Szerokość barków (a-a) (shoulders width) (cm) & 40,40 & 2,26 & 43,15 & 2,05 & 43,07 & 1,89 & 43,19 & 2,48 & 42,43 & 2,14 & 56,98 & 2,95 & 42,72 & 1,93 \\
\hline Szerokość bioder (ic-ic) (hips width) $(\mathrm{cm})$ & 29,05 & 1,34 & 30,95 & 1,88 & 30,59 & 2,19 & 31,08 & 2,32 & 29,78 & 1,94 & 31,90 & 2,03 & 31,03 & 2,67 \\
\hline Szerokość miednicy (is-is) (pelvis width) $(\mathrm{cm})$ & 23,36 & 1,59 & 24,87 & 1,41 & 24,23 & 2,29 & 24,88 & 1,96 & 24,02 & 1,41 & 24,72 & 1,91 & 24,88 & 1,74 \\
\hline Szerokość ręki (mm-mu) (arm width) $(\mathrm{cm})$ & 10,77 & 0,99 & 10,92 & 1,12 & 10,93 & 0,64 & 10,75 & 0,64 & 11,14 & 0,63 & 11,09 & 0,67 & 11,18 & 0,88 \\
\hline Szerokość dłoni ( $\mathrm{mr}-\mathrm{mu})$ (palm width) (cm) & 8,77 & 0,54 & 8,86 & 0,61 & 8,78 & 0,64 & 8,57 & 0,55 & 8,62 & 0,42 & 8,60 & 0,64 & 8,58 & 0,64 \\
\hline Szerokość stopy (mtt-mtf) (foot width) $(\mathrm{cm})$ & 10,17 & 0,39 & 10,32 & 0,42 & 10,14 & 0,67 & 10,43 & 0,50 & 10,44 & 0,67 & 10,52 & 0,71 & 10,24 & 0,78 \\
\hline $\begin{array}{l}\text { Ob. klatki piersiowej wdech (chest circumference inspiration) } \\
(\mathrm{cm})\end{array}$ & 101,9 & 5,82 & 96,5 & 5,92 & 97,31 & 4,99 & 100,61 & 6,31 & 97,04 & 4,30 & 99,31 & 5,73 & 99,06 & 5,05 \\
\hline $\begin{array}{l}\text { Ob. klatki piersiowej wydech }(\mathrm{cm}) \text { (chest circumference } \\
\text { expiration) }(\mathrm{cm})\end{array}$ & 94,08 & 5,33 & 90,55 & 6,02 & 91,82 & 5,53 & 93,62 & 3,03 & 91,15 & 3,90 & 94,48 & 5,62 & 93,97 & 4,91 \\
\hline Ob. pasa (waist cirumference) $(\mathrm{cm})$ & 80,96 & 3,54 & 81,2 & 5,76 & 78,02 & 5,32 & 82,69 & 6,78 & 79,35 & 4,62 & 79,62 & 5,52 & 79,31 & 3,95 \\
\hline Ob. bioder (hips circumference) $(\mathrm{cm})$ & 93,37 & 6,03 & 96,0 & 5,68 & 95,53 & 6,15 & 96,14 & 4,79 & 93,85 & 5,70 & 98,66 & 5,27 & 92,47 & 4,25 \\
\hline WHR (Talia / biodra) Wist to Hip Ratio & 0,85 & 0,03 & 0,84 & 0,04 & 0,82 & 0,04 & 0,86 & 0,05 & 0,84 & 0,04 & 0,81 & 0,04 & 0,86 & 0,04 \\
\hline Ob. r.napietego (arm circumference flexed) $(\mathrm{cm})$ & 34,04 & 2,63 & 30,1 & 3,13 & 32,78 & 2,28 & 33,74 & 3,28 & 33,40 & 1,95 & 33,69 & 2,87 & 33,48 & 3,52 \\
\hline Ob. ram. bez napięcia (arm circumference unflexed)(cm) & 30,04 & 1,61 & 29,05 & 0,65 & 29,93 & 2,67 & 29,85 & 2,83 & 29,74 & 1,70 & 29,95 & 2,60 & 30,01 & 3,47 \\
\hline AMC Arm Muscle Circumference & 27,20 & 2,68 & 27,50 & 3,21 & 27,11 & 2,42 & 26,61 & 2,54 & 29,46 & 1,67 & 28,51 & 2,19 & 27,41 & 3,54 \\
\hline Obwód uda (thigh circumference) $(\mathrm{cm})$ & 55,60 & 3,63 & 54,80 & 3,05 & 52,93 & 3,77 & 56,21 & 3,83 & 55,57 & 3,60 & 54,58 & 3,16 & 55,17 & 3,04 \\
\hline Obwód łydki (calf circumference) $(\mathrm{cm})$ & 37,42 & 2,11 & 36,95 & 3,08 & 36,78 & 2,82 & 38,22 & 2,45 & 37,30 & 2,45 & 36,44 & 2,39 & 36,99 & 2,33 \\
\hline
\end{tabular}

Table 2. The somatic characteristics (mean values and standard deviations) of men in the years $2006-2012$

\begin{tabular}{|c|c|c|c|c|c|c|c|c|c|c|c|c|c|c|}
\hline \multirow[b]{2}{*}{ Tested feature } & \multicolumn{2}{|c|}{$2006 \mathrm{~N}=41$} & \multicolumn{2}{|c|}{$2007 \mathrm{~N}=37$} & \multicolumn{2}{|c|}{$2008 \mathrm{~N}=32$} & \multicolumn{2}{|c|}{$2009 \mathrm{~N}=43$} & \multicolumn{2}{|c|}{$2010 \mathrm{~N}=\mathbf{2 6}$} & \multicolumn{2}{|c|}{$2011 \mathrm{~N}=\mathbf{2 0}$} & \multicolumn{2}{|c|}{$2012 \mathrm{~N}=18$} \\
\hline & $\bar{X}$ & $\mathrm{~S}$ & $\bar{X}$ & $\mathrm{~S}$ & $\bar{X}$ & $\mathrm{~S}$ & $\bar{X}$ & $\mathrm{~S}$ & $\bar{X}$ & $\mathrm{~S}$ & $\bar{X}$ & $\mathrm{~S}$ & $\bar{X}$ & $\mathrm{~S}$ \\
\hline Wysokość (body height) $(\mathrm{cm})$ & 169,83 & 4,80 & 170,0 & 4,97 & 170,01 & 7,02 & 169,0 & 6,0 & 167,4 & 8,02 & 165,0 & 5,0 & 171,98 & 13,40 \\
\hline Masa ciała( body mass) $(\mathrm{kg})$ & 63,82 & 7,40 & 63,7 & 6,66 & 64,3 & 6,36 & 63,0 & 7,97 & 65,72 & 6,52 & 61,3 & 6,75 & 63,88 & 16,22 \\
\hline Wskaźnik BMI ( body mass index) & 21,32 & 1,49 & 22,0 & 1,92 & 22,3 & 1,7 & 22,2 & 5,4 & 23,61 & 1,71 & 22,4 & 2,7 & 21,46 & 3,30 \\
\hline Masa tłuszczu w ciele FM (kg) (fat mass) & 19,21 & 3,94 & 16,3 & 3,44 & 18,34 & 3,25 & 19,30 & 3,27 & 19,23 & 3,01 & 16,29 & 4,34 & 14,67 & 6,39 \\
\hline Procentowa zawartość tluszczu FM (\%) (fat mass) & 29,45 & 3,44 & 25,4 & 3,50 & 28,38 & 2,80 & 30,49 & 1,96 & 29,23 & 3,08 & 26,20 & 4,27 & 22,78 & 5,24 \\
\hline Beztluszczowa masa ciała FFM (fat free mass) (kg) & 44,60 & 4,08 & 47,4 & 4,28 & 45,93 & 3,66 & 43,73 & 5,00 & 46,46 & 4,78 & 45,00 & 3,15 & 49,21 & 10,79 \\
\hline Beztluszczowa masa ciała FFM (fat free mass) $(\%)$ & 70,55 & 3,43 & 74,60 & 3,52 & 71,62 & 2,80 & 69,51 & 1,96 & 70,77 & 3,08 & 73,80 & 4,27 & 77,22 & 5,24 \\
\hline Fałd pod łopatką (subscapular skinfold) $(\mathrm{mm})$ & 12,10 & 4,00 & 12,78 & 4,33 & 14,20 & 5,55 & 13,75 & 6,1 & 11,81 & 2,95 & 9,5 & 3,4 & 7,16 & 3,38 \\
\hline Fałd nad tricepsem (skinfold over triceps) (mm) & 11,80 & 2,90 & 14,34 & 4,28 & 12,9 & 3,72 & 15,1 & 2,76 & 12.32 & 2,99 & 9,2 & 3,45 & 6,58 & 3,11 \\
\hline Fałd nad biodrem (suprailiac skinfold) (mm) & 12,40 & 3,30 & 13,71 & 4,45 & 10,21 & 2,71 & 12,0 & 2,82 & 12,31 & 3,19 & 10,9 & 3,91 & 8,21 & 3,66 \\
\hline Suma fałdów (skinfolds in total) (mm) & 37,30 & 3,50 & 40,83 & 4,35 & 34,21 & 8,01 & 39,70 & 6,11 & 36,50 & 7,80 & 29,7 & 10,5 & 21,94 & 9,57 \\
\hline D1. ramienia (a-r) (arm length) $(\mathrm{cm})$ & 28,25 & 2,25 & 26,0 & 2,27 & 29,04 & 1,65 & 32,09 & 3,47 & 30,82 & 2,62 & 30,93 & 2,79 & 30,39 & 5,64 \\
\hline D1. przedramienia $(\mathrm{r}-\mathrm{sty})$ (forearm length) $(\mathrm{cm})$ & 26,00 & 1,30 & 26,05 & 1,23 & 25,65 & 1,78 & 23,81 & 1,99 & 24,69 & 1,96 & 23,03 & 2,77 & 24,18 & 3,09 \\
\hline D1. kończyny górnej (a-daIII) (upper limb length) (cm) & 71,38 & 3,95 & 74,30 & 4,02 & 72,48 & 3,64 & 74,13 & 4,24 & 72,79 & 3,99 & 72,52 & 3,64 & 73,28 & 7,32 \\
\hline Dł. kończyny dolnej (tro-B) (leg length) $(\mathrm{cm})$ & 82,98 & 4,75 & 86,10 & 5,15 & 86,85 & 6,23 & 85,85 & 4,94 & 83,73 & 6,87 & 83,71 & 5,98 & 87,86 & 11,69 \\
\hline D1. stopy (pte-ap) (foot length) (cm) & 24,68 & 1,20 & 24,70 & 1,18 & 25,19 & 1,30 & 24,45 & 1,37 & 24,23 & 1,37 & 23,93 & 1,33 & 24,70 & 2,45 \\
\hline Długość tułowia (a-tro) (torso length) (cm) & & & & & & & & & 51,44 & 2,64 & 51,28 & 5,55 & 50,62 & 5,69 \\
\hline Szerokość barków (a-a) (shoulders width) $(\mathrm{cm})$ & 36,49 & 1,33 & 37,55 & 1,98 & 39,61 & 1,56 & 38,86 & 2,65 & 37,44 & 2,53 & 38,61 & 1,29 & 37,32 & 4,50 \\
\hline Szerokość bioder (ic-ic) (hips width) $(\mathrm{cm})$ & 29,39 & 1,75 & 31,80 & 2,88 & 32,62 & 3,32 & 30,51 & 1,95 & 30,56 & 1,96 & 31,27 & 2,04 & 31,57 & 7,17 \\
\hline Szerokość miednicy (is-is) (pelvis width) (cm) & 23,78 & 1,74 & 23,77 & 1,67 & 23,97 & 2,36 & 24,77 & 1,92 & 24,11 & 1,55 & 22,71 & 1,37 & 24,28 & 4,06 \\
\hline Szerokość ręki (mm-mu) (arm width) $(\mathrm{cm})$ & 9,65 & 0,81 & 9,87 & 0,77 & 9,59 & 0,35 & 9,78 & 0,49 & 9,75 & 0,48 & 9,73 & 0,52 & 9,66 & 0,82 \\
\hline Szerokość dłoni ( $\mathrm{mr}-\mathrm{mu})$ (palm width) $(\mathrm{cm})$ & 7,94 & 0,19 & 7,78 & 0,30 & 7,79 & 0,28 & 7,80 & 0,37 & 7,91 & 0,48 & 7,57 & 0,38 & 7,76 & 0,88 \\
\hline Szerokość stopy (mtt-mtf) (foot width) $(\mathrm{cm})$ & 9,32 & 0,20 & 9,36 & 0,35 & 9,35 & 0,52 & 9,30 & 0,45 & 9,31 & 0,50 & 9,13 & 0,63 & 9,16 & 0,90 \\
\hline Ob. klatki piersiowej wydech $(\mathrm{cm})$ (chest circumference expiration) $(\mathrm{cm})$ & 90,44 & 4,59 & 93,80 & 4,93 & 91,81 & 5,22 & 93,38 & 5,17 & 94,73 & 4,23 & 92,48 & 4,80 & 93,47 & 8,56 \\
\hline Ob. klatki piersiowej wydech $(\mathrm{cm})$ (chest circumference expiration) $(\mathrm{cm})$ & 89,02 & 4,24 & 88,90 & 4,98 & 87,66 & 4,62 & 88,65 & 5,78 & 90,84 & 4,33 & 88,89 & 4,81 & 89,31 & 9,33 \\
\hline Ob. pasa (waist cirumference) $(\mathrm{cm})$ & 72,59 & 5,23 & 75,2 & 6,64 & 71,57 & 3,45 & 76,03 & 6,50 & 74,89 & 6,04 & 70,03 & 6,53 & 70,39 & 9,70 \\
\hline Ob. bioder (hips cirumference) $(\mathrm{cm})$ & 95,60 & 4,45 & 96,30 & 5,04 & 97,11 & 5,43 & 94,47 & 5,82 & 95,28 & 4,57 & 94,77 & 5,21 & 88,72 & 11,78 \\
\hline WHR (Talia / biodra) Wist to Hip Ratio & 0,76 & 0,06 & 0,78 & 0,05 & 0,74 & 0,03 & 0,81 & 0,05 & 0,78 & 0,05 & 0,74 & 0,05 & 0,79 & 0,06 \\
\hline Ob. r.napietego (arm circumference flexed) $(\mathrm{cm})$ & 28,61 & 2,15 & 28,01 & 1,90 & 28,35 & 1,71 & 28,49 & 2,31 & 28,11 & 1,70 & 27,57 & 1,61 & 28,07 & 3,69 \\
\hline Ob. ram. bez napięcia (arm circumference unflexed) $(\mathrm{cm})$ & 26,06 & 2,03 & 26,40 & 1,35 & 26,76 & 1,69 & 26,20 & 2,39 & 25,87 & 1,38 & 25,52 & 1,81 & 26,28 & 3,62 \\
\hline AMC Arm Muscle Circumference & 22,90 & 1,20 & 21,50 & 2,04 & 22,81 & 1,30 & 21,45 & 1,79 & 25,43 & 1,57 & 22,61 & 1,50 & 24,21 & 3,30 \\
\hline Obwód uda (thigh circumference) $(\mathrm{cm})$ & 56,38 & 3,74 & 55,10 & 4,08 & 54,70 & 3,04 & 53,05 & 3,66 & 53,02 & 2,36 & 51,78 & 2,26 & 51,27 & 6,15 \\
\hline Obwód łydki (calf circumference) $(\mathrm{cm})$ & 38,71 & 2,08 & 37,12 & 2,05 & 36,68 & 1,72 & 36,83 & 2,73 & 36,09 & 1,72 & 34,00 & 2,07 & 34,09 & 5,16 \\
\hline
\end{tabular}

Table 3. The somatic characteristics (mean values and standard deviations) of women in the years $2006-2012$ 


\section{CONCLUSIONS:}

The anthropological issues are widely represented in the science of physical education as they are important for the formulation of the theory of structure and functioning of the human body. Anthropology of sport investigates into relationships and determines the theoretical basis of selection for the sport in the field of morpho-functional analysis of the body. The detailed evaluation of individual development based on a multi-faceted research can often anticipate the possibility of adaptation of the body to physical exercise (performance and capacity).

Date based on thorough analysis of the impact assessment of physical activity on body morphology, tissue composition and development of an individual is also often used. It may be necessary for the proper planning of sports training [4].

Anthropometry, which is the subject of researches, is a complex issue connected with adaptive changes in human body, depending on a variety of environmental factors.

The problem of short stature of children in rural areas can be a good example. It is examined by U. Czerniak et al. [5]. At the turn of March and April 2007, she conducted a survey in rural areas concerning the problems of growth, maturation and development of the somatic proportions during the development. They allowed the group to determine abiotic, biological and social factors influencing the level of biological development of children in rural areas. The analysis used research data of 145 girls and 140 boys aged 7-9 who were pupils at rural schools in the Greater Poland region. The analysis of body proportions of the average height and short stature children indicates the existence of some insignificant differences in the development of morphological structures. These characteristics are reflected in somatotypes of the subjects. Short-statured children differ slightly from the others. The domination of mesomorphy component is clearly visible in this group, indicating a greater solidity of construction.

At the turn of 2005/2006, the staff of [6] Department of Anthropology and Biometry started cooperation with the Academic Training Center and The Sports Association of Greater Poland. The created opportunities made them to undertake a research cycle among young athletes practicing different sports, and thus, enabled the assessment of morphological diversity of these athletes on the basis of somatic features. The purpose of the study was to determine the construction of somatic short-statured athletes. The measurements were conducted among 254 boys aged 15-17, who were at the stage of the process-oriented sports training and were the members of the sports representation of the Greater Poland region. The accumulated extensive set of characteristics was used to estimate the somatic factors defining the size and proportions of the body, and also allowed setting the body types using the Sheldon method modified by Heath and Carter. Among the 254 researched athletes $12 \%$ were of low height. They had similar body proportions. Moreover, these athletes achieved similar results of the analysed parameters and had similar places on the somatic card - the same as those noticed in athletes whose body height is above 10 centile. A smaller body height, similar construction that is characteristic for the particular sports discipline and very good athletic results can be a proof that individuals with good motor skills revealed themselves in a natural way.

The research documentary on students' body structure was created by the staff of the Department of
Bromatology of the Poznań University of Medical Sciences [7]. They tried to assess selected anthropometric parameters in students from Poznań. On the basis of height, weight, waist circumference, hip circumference and the thickness of skinfolds, the BMI, WHR and OMR parameters were determined as well as the percentage of body fat (96 FAI). It was found out that the analysed parameters in both examined groups of men and women were correct and within the ranges indicating a lack of overweight and obesity.

Referring to the results of the researches on students from Bydgoszcz that are presented in this study, we can conclude that the numerical values of the compared somatic parameters of students fluctuate; however, in the years 2006 - 2012 only a few showed statistically significant differences. The problem needs further studies.

\section{REFERENCES:}

1. Wolański N., (2006), Rozwój biologiczny człowieka, Wydawnictwo Naukowe PWN, Warszawa.

2. Roy J., Shephard M. D., (1987), Exercise physiology. BC Decker INC, Toronto, Philadelphia.

3. Drozdowski Z., (2002), Antropologia dla nauczycieli wychowania fizycznego, AWF, Poznań.

4. Brener ND., Mcmanus T., Galuska DA., Lowry R., (2003), Wechsler H., Reliability and validity of self-reported height and weight among high school students, Journal Adolesc Health, Vol. 32 (4), pp. 281-287.

5. Czerniak U., Demuth A., Krzykała M., Janowski J,(2007). Niskorosłość dzieci wiejskich w świetle badań antropometrycznych, „Pediatric Endocrinology”, Diabetes and Metabolizm, Vol. 13/3, pp. $130-134$

6. Demuth A., Czerniak U., Krzykała M. (2008). Niskorosłość sportowców w świetle badań antropometrycznych. „Pediatric Endocrinology, Diabetes and Metabolizm”, Vol. 14/3, pp. $171-176$

7. Kaźmierczak A., Bolesławska I., Główka A.,Anna Dzięcioł M., Przysławski J. (2012). Ocena wybranych parametrów antropometrycznych wśród młodzieży akademickiej Poznania, „Bromat. Chem. Toksykol.”, XLV/3, pp. 10991104

Address for correspondence:

Jerzy Eksterowicz

Uniwersytet Kazimierza Wielkiego w Bydgoszczy

Instytut Kultury Fizycznej

Bydgoszcz ul. Sportowa 2

tel.: 601639181

e-mail: jekster@interia.pl

Received: 05.02.2013

Acceoted for publication: 07.01.2014 